\title{
FUZJE I PRZEJĘCIA W SEKTORZE BANKOWYM A STRUKTURA KONKURENCYJNA RYNKU USŁUG BANKOWYCH W POLSCE OD ROKU 2004
}

\begin{abstract}
WSTĘP
Konkurencja na rynku usług bankowych, ze względu na rolę, jaką sektor bankowy odgrywa w systemie finansowym państwa, pozostaje przedmiotem zainteresowania naukowców od wielu lat ${ }^{1}$. Niniejsze opracowanie, wpisujące się we wspomniany nurt badań, poświęcono określeniu konkurencji na rynku usług bankowych w Polsce przy użyciu metod strukturalnych. Dotychczasowe opracowania na temat struktury konkurencyjnej polskiego rynku usług bankowych wskazują na istnienie konkurencji monopolistycznej jako struktury organizującej jego funkcjonowanie ${ }^{2}$.

Rozwój współczesnych sektorów bankowych zdominowany został przez dwa procesy - konsolidację i deregulację $e^{3}$ Pierwszy proces prowadzi do wzrostu koncentracji i umożliwia czerpanie z korzyści skali, drugi - wzmaga konkurencję

\footnotetext{
1 Por. m.in.: W.R. Emmons, F.A. Schmid, Bank Competition and Concentration: Do Credit Unions Matter?, „Federal Reserve Bank of St. Louis Review” 2000, vol. 82, No. 3, s. 29-42; J.A. Bikker,J.M. Groeneveld, Competition and Concentration in the EU Banking Industry, ,Journal of Banking and Finance" 2002, No. 26, s. 2191-2214; S. Claessens, L. Laeven, What Drives Bank Competition? Some International Evidence, „Journal of Money, Credit and Banking” 2004, No. 36, s. 563-583; M. Affinito, M. Piazza, What determines banking structures in European regions?, Bank of Italy Working Paper 2005, No. 8, s. 1-41; C. Giannetti, Intensity of Competition and Market Structure in the Italian Banking Industry, „CORE Discussion Papers” 2007, No. 41, s. 1-32; M. Pawłowska, Competition in the Polish Banking Sector, „Gospodarka Narodowa” 2010, No. 5-6, s. 91-119.

2 R.G. Gelos, J. Roldos, Consolidation and Market Structure in Emerging Banking Systems, IMF Working Paper 2002, No. 2 (186), s. 17; S. Claessens, L. Laeven, op. cit., s. 29; M. Pawłowska, Wptyw procesów konsolidacyjnych na poziom konkurencji i efektywnośc systemów bankowych - wyniki badań ilościowych, [w:] Konkurencyjność sektora bankowego po wejściu Polski do Unii Europejskiej, red. E. Balcerowicz, Zeszyty BRE Bank - CASE 2005, nr 76, s. 38 i 41.

M. Pawłowska, Competition in the Polish, s. 91.
} 
między podmiotami ${ }^{4}$. W rezultacie powstaje struktura konkurencyjna, która ma istotne znaczenie dla cen płaconych przez konsumentów. W artykule podjęto się odpowiedzi na pytanie, jak procesy konsolidacji właścicielskiej w sektorze bankowym wpłynęły na poziom koncentracji rynku usług bankowych w Polsce.

Celem opracowania jest analiza poziomu koncentracji rynku usług bankowych w Polsce po pięciu latach od akcesji do Unii Europejskiej. Zgodnie z ustaleniami mikroekonomii wzrostowi koncentracji towarzyszyć powinien spadek konkurencji. Ponadto zakłada się, że wraz z postępującym procesem konsolidacji wzrasta poziom koncentracji.

W empirycznej części opracowania ujęto dane charakteryzujące pięcioletni okres funkcjonowania banków komercyjnych w Polsce. Za początek analizy przyjęto okres akcesji do struktur Unii Europejskiej, tj. rok 2004. Analizę zakończono na ostatnich, dostępnych w chwili przygotowywania niniejszego opracowania danych, tj. na 2009 roku. Źródłem informacji finansowych, na podstawie których dokonano analiz, jest baza danych BankScope ${ }^{5}$.

\section{KONSOLIDACJA SEKTORA BANKOWEGO W POLSCE PO AKCESJI DO UNII EUROPEJSKIEJ}

Przyczyny fuzji i przejęć w sektorze bankowym w Polsce na podstawie doświadczeń lat 90 . XX wieku są przedmiotem obszernych analiz w literaturze przedmiotu ${ }^{6}$. Połączenia banków w Polsce miały wówczas etapowy przebieg: do 1996 roku fuzje i przejęcia miały charakter głównie sanacyjny, w latach 1997 - 1999 dominowały fuzje i przejęcia podmiotów w dobrej sytuacji ekonomicznej oraz tzw. konsolidacja odgórna, po 1999 roku dominowała konsolidacja właścicielska ${ }^{7}$. W rezultacie kolejnych ogromnych fuzji w latach 1997-2002 wzrastały wskaźniki koncentracji rynku usług bankowych w Polsce ${ }^{8}$.

W pierwszych latach funkcjonowania Polski w strukturach Unii Europejskiej procesy konsolidacji w sektorze bankowym przebiegały w ograniczonym stopniu.

\footnotetext{
4 Ibidem.

5 Serwis internetowy Bureau van Dijk: https://bankscope2.bvdep.com (data dostępu: 10 marca 2011 r.). Baza zawiera kompleksowe informacje na temat finansów ponad 23 tys. banków.

6 Fuzje i przejęcia bankowe, red. E. Balcerowicz, Zeszyty BRE Bank-CASE, nr 45, Warszawa 1999, s. 16-17, M. Pawłowska, Wptyw zmian w strukturze polskiego sektora bankowego na jego efektywnoś w latach 1997-2002 (podejsicie nieparametryczne), „Bank i Kredyt” 2003, nr 11-12, s. 52-53; J. Kraciuk, Procesy konsolidacji w polskim sektorze bankowym, [w:] Problemy rolnictwa światowego, red. H.M. Szoege, W.E. Tyner, Zeszyty Naukowe SGGW, t. XV, Warszawa 2006, s. 285-286.

7 Szerzej K. Stępień, Konsolidacja a efektywnośc banków w Polsce, CeDeWu, Warszawa 2004, s. 123. Wykaz połączeń bankowych znajdujemy w: M. Pawłowska, Wplyw zmian, s. 53.

8 M. Pawłowska, Wptyw zmian, s. 52.
} 
Celem kolejnych fuzji było zwiększanie udziału w rynku i realizacja założeń inwestorów. Zainteresowanie inwestorów zagranicznych polskimi bankami wzrosło w okresie kryzysu finansowego. Część instytucjonalnych inwestorów z Europy Zachodniej była bądź będzie zmuszona wycofać się z polskiego rynku usług bankowych w celu ratowania posiadanych aktywów na innych rynkach ${ }^{9}$. Jednocześnie nowi inwestorzy zagraniczni chętnie przejmują polskie banki, posiadające dobrą sytuację finansową oraz funkcjonujące na rozwijającym się rynku ${ }^{10}$. Proces konsolidacji właścicielskiej w polskim sektorze bankowym od 2004 roku do końca pierwszego kwartału 2011 roku przedstawiono w tabeli 1. Zestawienie uwzględnia najważniejsze fuzje i przejęcia, z pominięciem zjawiska rebrandingu wynikającego z połączenia zagranicznych spółek-matek, lecz niemającego wpływu na zmianę pozycji rynkowej banku bądź grupy bankowej w Polsce.

Tabela 1. Połączeniaa) banków komercyjnych w Polsce w latach 2004-2011 ${ }^{\text {b) }}$

\begin{tabular}{|c|c|}
\hline BANK PO FUZJ LUB PRZEEECIU & BANKI UCZESTNICZĄE W PROCESIE \\
\hline \multicolumn{2}{|r|}{2004} \\
\hline Getin Bank SA & Getin Bank SA przejął aktywa i pasywa Banku Przemysłowego SA \\
\hline GE Money Mank SA & Połączono banki GE Capital Bank SA i GE Bank Mieszkaniowy SA \\
\hline \multicolumn{2}{|r|}{2007} \\
\hline Bank Pekao SA & $\begin{array}{l}\text { Bank Pekao SA przejął 80\% aktywów Banku BPH SA (w tym BPH Banku Hipo- } \\
\text { tecznego SA) w efekcie połączenia ówczesnych właścicieli obu banków, tj. Grupy } \\
\text { UniCredit oraz Banku HVB }\end{array}$ \\
\hline \multicolumn{2}{|r|}{2009} \\
\hline Fortis Bank Polska SA & Fortis Bank Polska SA przejął Dominet Bank SA \\
\hline Bank BPH SA & $\begin{array}{l}\text { General Electric Company - właściciel banków Banku BPH SA i GE Money Bankiem } \\
\text { SA - dokonał ich fuzji }\end{array}$ \\
\hline \multicolumn{2}{|r|}{2010} \\
\hline Getin Noble Bank SA & Dokonano fuzji Getin Banku SA z Noble Bankiem SA \\
\hline Santander Consumer Bank SA & Dokonano fuzji Santander Consumer Bank SA z AIG Bank Polska SA \\
\hline $\begin{array}{l}\text { BNP Paribas Fortis SA (nazwa handlowa } \\
\text { Fortis Bank Polska SA) }\end{array}$ & Fortis Bank Polska SA przejmuje aktywa klientów BNP Paribas SA Oddział w Polsce \\
\hline & 2011 \\
\hline
\end{tabular}

$9 \quad$ Przykładem jest irlandzka grupa kapitałowa AIB, która zdecydowała się sprzedać Bank Zachodni WBK SA w celu ratowania swoich spółek na rynku amerykańskim.

10 Przykładem jest hiszpański Santander Bank, który w latach 2010-2011 przejął kontrolę nad Bankiem Zachodnim WBK SA oraz AIG Bankiem Polska SA. 
cd. tab. 1

\begin{tabular}{|c|c|}
\hline BANK PO FUZJ LUB PRZEJĘIU & BANKI UCZESTNIIZZ̨CE W PROCESIE \\
\hline Raiffeisen Bank Polska SA & $\begin{array}{l}\text { Raiffeisen Bank International AG osiągnął porozumienie w sprawie przejęcia 70\% } \\
\text { udziałów w Polbank EFG (nazwa handlowa EFG Eurobank Ergasias S.A. Spółka } \\
\text { Akcyjna Oddział w Polsce). Polbankiem zainteresowany był również PKO BP SA }\end{array}$ \\
\hline Bank Zachodni WBK SA & $\begin{array}{l}\text { Santander Consumer Bank SA przejął pakiet 70\% akcji Banku Zachodniego WBK } \\
\text { SA od irlandzkiej grupy kapitałowej AIB. Zainteresowanie przejęciem BZWBK wy- } \\
\text { raził również Bank PKO BP SA oraz BNP Paribas }\end{array}$ \\
\hline
\end{tabular}

Uwagi: a) w zestawieniu nie uwzględniono zmian nazw banków wynikających z fuzji zagranicznych spółek-matek, ${ }^{\text {b) }}$ dane za pierwszy kwartał 2011 roku.

Źródło: opracowanie własne.

\section{STRUKTURALNE MIARY KONCENTRACJ RYNKU USŁUG BANKOWYCH}

W literaturze przedmiotu powszechnie stosuje się miary koncentracji rynku oparte na krzywej koncentracji ${ }^{11}$, takie jak udział w rynku największych dostawców $\left(C R_{n}\right)$. Wskaźnik $C R_{n}$ jest prostą miarą koncentracji rynku, polegającą na wyliczeniu procentowego udziału $n$-największych dostawców w wybranej kategorii charakteryzującej rynek. Dla uporządkowanego malejąco zbioru obserwacji obliczamy go według wzoru:

$$
C R_{n} \sum_{i=1}^{n} u_{i}
$$

gdzie $u_{i}$ to udział $i$-tego dostawcy w rynku, $n$ to liczba dostawców, przy czym w odniesieniu do jednej branży najczęściej przyjmowanymi wartościami parametru $n$ są liczby: 3, 4, 5, 8, 10 i $15^{12}$. W odniesieniu do sektora bankowego zwykle oblicza się udział w aktywach, kredytach i depozytach.

Miarą koncentracji rynku może być także współczynnik Giniego $(G)$, określany w literaturze jako miara nierówności rozkładu ${ }^{13}$. Wyprowadza się go, stosując

11 Krzywa powstała wskutek połączenia punktów o następujących współrzędnych $\left(N,=\sum_{i=1}^{n} u_{i}\right)$, gdzie $N$ - numer dostawcy w zbiorze uporządkowanym według malejącego udziału w rynku, $n$-liczba dostawców, $u_{i}$ - udział $i$-tego dostawcy w rynku.

12 K. Jackowicz, O. Kowalewski, Koncentracja dziatalności sektora bankowego w Polsce w latach 1994-2000, NBP, „Materiały i Studia” 2002, nr 143, s. 8.

13 C.W. Gini, Variability and Mutability, contribution to the study of statistical distributions and relations, „Studi Economico-Giuridici della R. Universita de Cagliari” 1912, przedruk w: R.J. Light, B.H. Margolin, An analysis of variance for categorical data, „Journal of the American Statistical Association" 1971, No. 66, s. 534-554, http://www.jstor.org/stable/2283520 (data dostępu: 01.03.2011 r.). 
krzywą Lorenza ${ }^{14}$. Dla uporządkowanej w kolejności rosnącej próby obserwacji współczynnik $G$ można obliczyć, korzystając z następujących wzorów:

$$
G_{1}=\frac{\sum_{i=1}^{n}(2 i-n-1) x_{i}}{n^{2} \bar{x}}, \text { gdzie } \bar{x}=\frac{1}{n} \sum_{i=0}^{n} x_{1} \text { lub } G_{2} \frac{\sum_{i=1}^{n}(2 i-n-1) x_{i}}{(n-1) \sum_{i=1}^{n} x_{i}}
$$

Wskaźnik Giniego przyjmuje wartości od 0 do $\left(1-\frac{1}{n}\right)$, przy czym wraz ze wzrostem wskaźnika następuje wzrost koncentracji cechy.

Indeks Herfindahla-Hirschmana $(H H I)$ jest nieco bardziej zaawansowaną miarą koncentracji rynku. Oblicza się go jako sumę kwadratów udziałów w rynku każdego konkurującego dostawcy. W przeciwieństwie do wskaźnika koncentracji $C R_{n}$, indeks HHI zależy zarówno od zróżnicowania udziału w rynku, jak i liczby dostawców. Osiąga on wartość bliską zeru i równą $1 / n$ (gdzie $n$ to liczba dostawców) wówczas, gdy rynek składa się z dużej liczby małych i równych podmiotów i przybiera maksymalną wartość jeden dla monopolu. Obliczamy go według formuły: $\mathrm{HHI}=\sum_{i=1}^{n} u_{i}^{2}$, gdzie $u_{i}-$ udział $i$-tego dostawcy w rynku, $n-$ liczba
dostawców.

HHI poniżej 0,1 wskazuje na nieskoncentrowany rynek. Wartość indeksu w przedziale pomiędzy 0,1 a 0,18 sygnalizuje średnią koncentrację rynku. $H H I$ powyżej 0,18 wskazuje na wysoką koncentrację rynku. Spadek indeksu Herfindahla-Hirschmana na ogół oznacza spadek zdolności do wpływania na cenę, co prowadzi do wzrostu konkurencji.

\section{KONCENTRACJA W POLSKIM SEKTORZE BANKOWYM W LATACH 2004-2009}

Analizy koncentracji rynku usług bankowych dokonano, opierając się na zdefiniowanych wyżej strukturalnych miarach koncentracji w odniesieniu do dwóch wielkości: aktywów oraz wyników netto banków komercyjnych. Udział w aktywach największych banków w Polsce był ustalony i niezmienny w całym badanym okresie. W latach 2004-2009 ponad 50\% aktywów skoncentrowane było w pięciu największych bankach: Powszechnej Kasie Oszczędności Banku Polskim SA,

14 Krzywa, wykreślona przez M.O. Lorenza w 1905 roku dla zilustrowania nierównomiernego rozkładu bogactwa, powstała wskutek połączenia punktów o następujących współrzędnych $\left(\frac{N}{n}, \sum_{i=1}^{n} u_{i}\right)$, gdzie $N$ - numer dostawcy w zbiorze uporządkowanym według rosnącego udziału w ryn$\mathrm{ku}, n$ - liczba dostawców, $u_{i}$ - udzial $i$-tego dostawcy w rynku. Por. M.O. Lorenz, Methods of measuring the concentration of wealth, „Publications of the American Statistical Association” 1905, vol. 9, No. 70, s. 209-219, http://www.jstor.org/stable/2276207 (data dostępu: 02.03.2011 r.). 
Banku Pekao SA, BRE Banku SA, ING Banku Śląskim SA oraz Banku Zachodnim WBK SA (por. wykres 1).

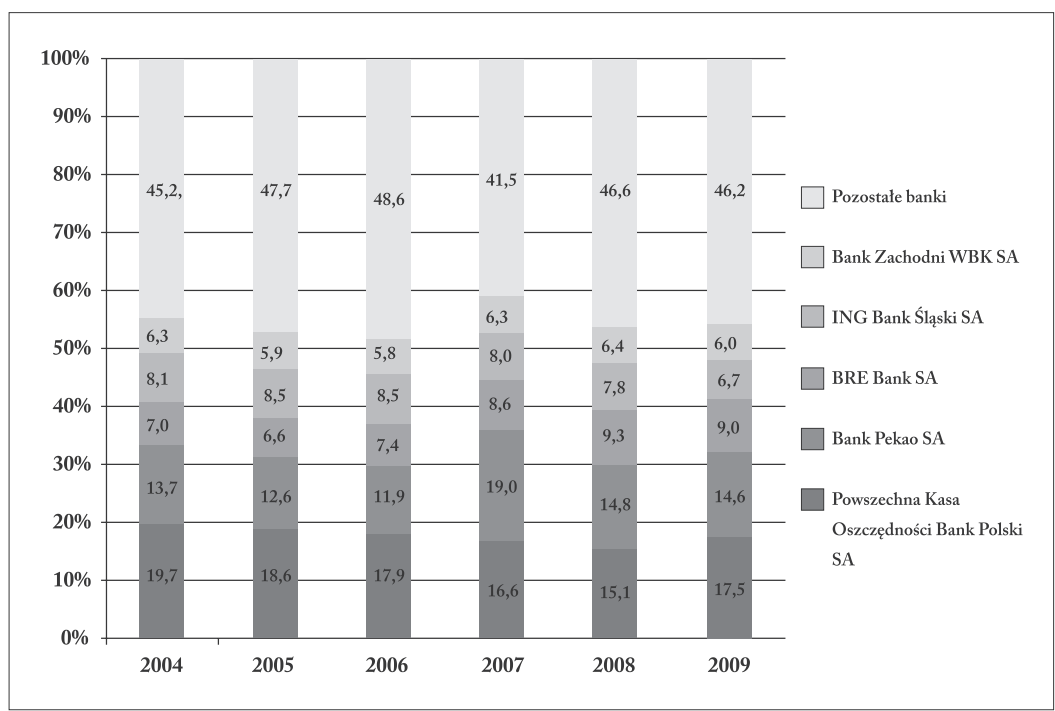

Wykres 1. Aktywa banków komercyjnych (\% ogółu) w latach 2004-2009

Źródło: opracowanie własne.

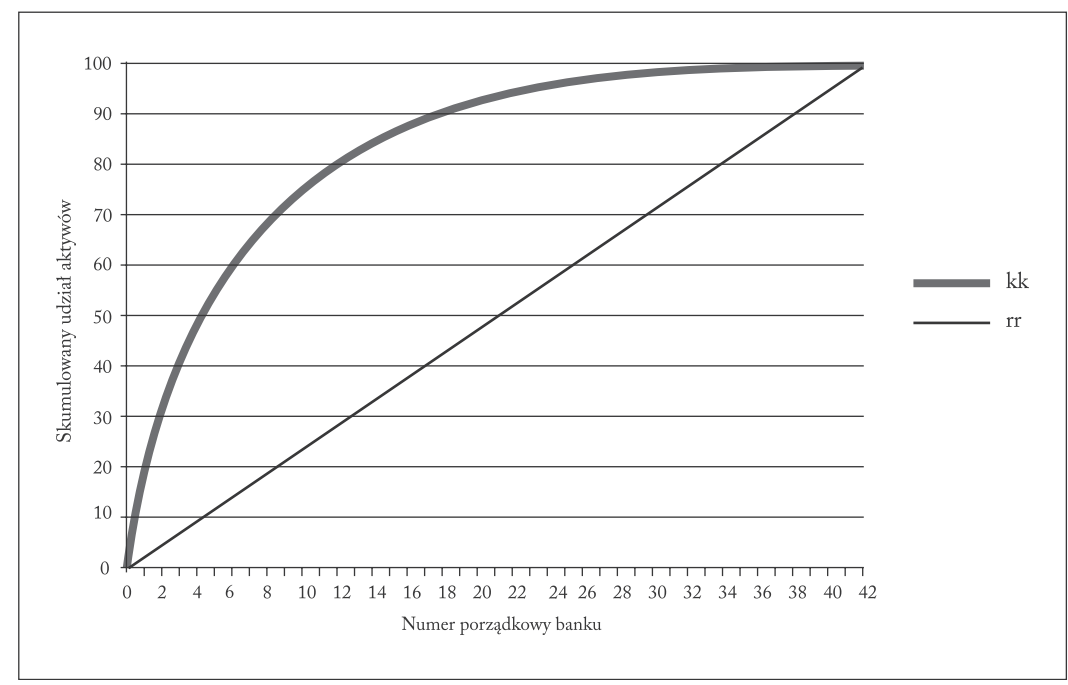

Wykres 2. Krzywa koncentracji aktywów sektora bankowego w 2009 roku

Źródło: opracowanie własne.

Pewne zmiany w rankingu banków dokonały się w 2007 roku, kiedy to w wyniku wspomnianego już przejęcia części aktywów Banku BPH SA - przej- 
ściowo Bank Pekao SA przejął pozycję lidera od PKO BP SA. Ponadto BRE Bank SA zamienił na trzeciej pozycji w rankingu ING Bank Śląski SA.

Wykres 2 ilustruje krzywą koncentracji (kk) aktywów w bankach komercyjnych w Polsce. Na osi rzędnych odłożono skumulowany udział $n$-kolejnych banków w aktywach banków komercyjnych ogółem. $\mathrm{Na}$ osi odciętych uszeregowano banki komercyjne według aktywów w porządku malejącym, przypisując im pozycje od 1 do 42 . Uzyskana w ten sposób krzywa znacząco odbiega od linii ilustrującej rozkład równomierny $(r r)$. Na podstawie krzywej koncentracji można wyznaczyć udział największych instytucji kredytowych w aktywach ogółem.

Wskaźnik koncentracji aktywów $C R_{5}$ utrzymywał się w badanym okresie w przedziale od 50 do $60 \%$ (por. wykres 3). Pozostałe wskaźniki koncentracji aktywów $C R_{10}, C R_{15}$ - dzięki szybkiemu rozwojowi aktywów banków średnich i małych - wykazywały tendencję malejącą. Udział 10 największych banków obniżył się o ponad 11 punktów procentowych, a udział 15 największych banków spadł o ponad 4 punkty procentowe ${ }^{15}$.

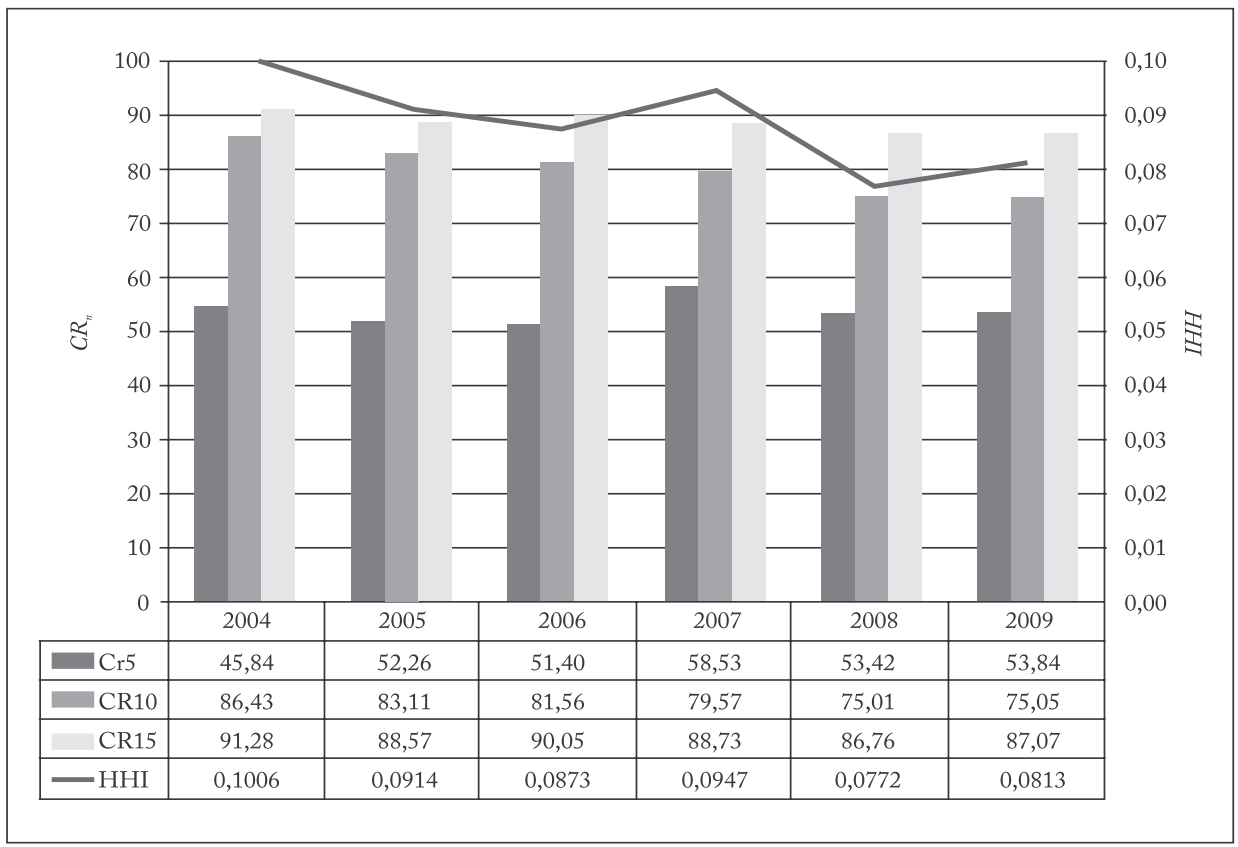

Wykres 3. Wskaźniki $C R_{5^{\prime}} C R_{10^{\prime}} C R_{15}$ i HHI dla aktywów sektora bankowego w latach 2004-2009

Źródło: opracowanie własne.

15 Podobne wyniki otrzymano w zakresie koncentracji kredytów i depozytów sektora banków komercyjnych. Ze względu na narzucone ograniczenia w długości niniejszego tekstu zrezygnowano $\mathrm{z}$ ich prezentacji. 
$\mathrm{Na}$ niski i malejący poziom koncentracji wskazuje również HHI. Za wyjątkiem roku 2004, poziom wskaźnika HHI wskazuje na nieskoncentrowany rynek usług bankowych w Polsce (por. wykres 3). Dzięki szybszemu wzrostowi aktywów banków średnich i małych wskaźnik ten zmalał w badanym okresie.

Wykres 4 ilustruje krzywą Lorenza $(k l)$ dla aktywów banków komercyjnych w Polsce. Skale obu osi wykresu ograniczone są maksymalną wartością 1 . Na osi odciętych odłożono relację powstałą w wyniku podzielenia numeru kolejnego banku przez ogólną liczbę banków komercyjnych, przy czym banki uporządkowane były według rosnącego udziału aktywów. Oś rzędnych ilustruje skumulowany udział $n$-kolejnych instytucji w aktywach banków komercyjnych. Uzyskana w ten sposób linia pozwala poczynić m.in. następujące obserwacje: 50\% najmniejszych banków kontroluje 6\% aktywów, 81\% banków kontroluje 33\% aktywów sektora bankowego, natomiast 95,2\% banków kontroluje 68\% aktywów. Stąd wniosek, że rozkład aktywów odbiega znacząco od rozkładu równomiernego, który na wykresie 4 ilustruje linia $r r$. W efekcie wartość współczynnika Giniego wyniosła: $G_{1}=79,67 \% ; G_{2}=81,76 \%$. W analizie koncentracji można odwołać się do tzw. zasady Pareto, w myśl której ze znaczną koncentracją rynku mamy do czynienia wówczas, gdy $20 \%$ wszystkich jednostek realizuje $80 \%$ obserwacji (w tym wypadku posiada 80\% aktywów). Wskaźnik Giniego dla koncentracji aktywów wskazuje, że rynek usług bankowych w Polsce znajduje się blisko granicy wysokiej koncentracji.

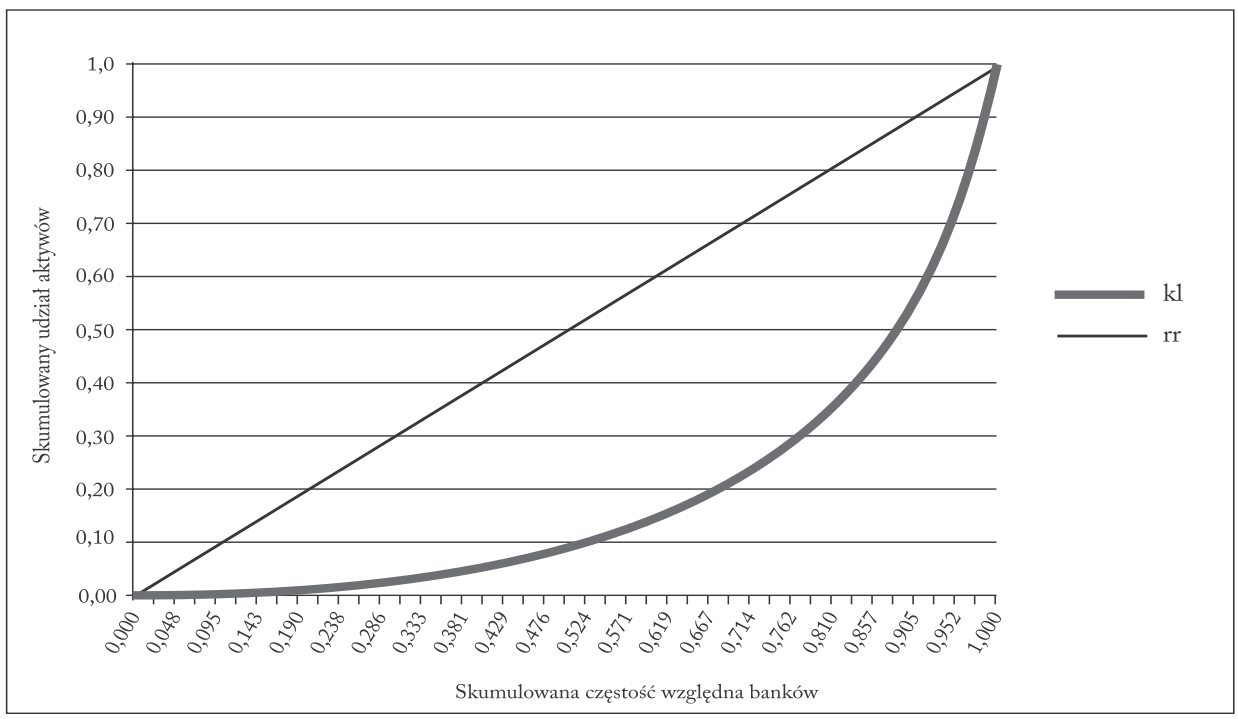

Wykres 4. Krzywa Lorenza dla aktywów sektora bankowego w 2009 roku

Uwaga: Wartość współczynnika Giniego: $G_{1}=79,67 \% ; G_{2}=81,76 \%$.

Źródło: opracowanie własne. 
Relatywnie większy stopień koncentracji wykazują wyniki netto sektora bankowego w Polsce. W latach 2008-2009 od 51,9 do 58,2\% zysków netto koncentrowało się w dwóch największych bankach, tj. Banku Pekao SA oraz PKO BP SA (por. wykres 5). Podczas gdy jeszcze w 2008 roku pięć najbardziej zyskownych banków przejęło 71,3\% zysków, to już w 2009 roku udział w wyniku netto tej grupy banków wzrósł do 83,3\%. W 2009 roku ING Bank Śląski SA zajął 4 miejsce, wcześniej zarezerwowane dla BRE Banku SA, który tym samym wypadł poza pierwszą piątkę. Wskaźniki $C R_{10}$ i $C R_{15}$ wyniosły odpowiednio 91,5 oraz $96 \%$.

Wysoki poziom koncentracji wyników netto prowadzić będzie do wzrostu znaczenia największych podmiotów na rynku, co w przyszłości skutkować może spadkiem konkurencji między bankami i pogłębianiem koncentracji wokół kilku największych instytucji bankowych.
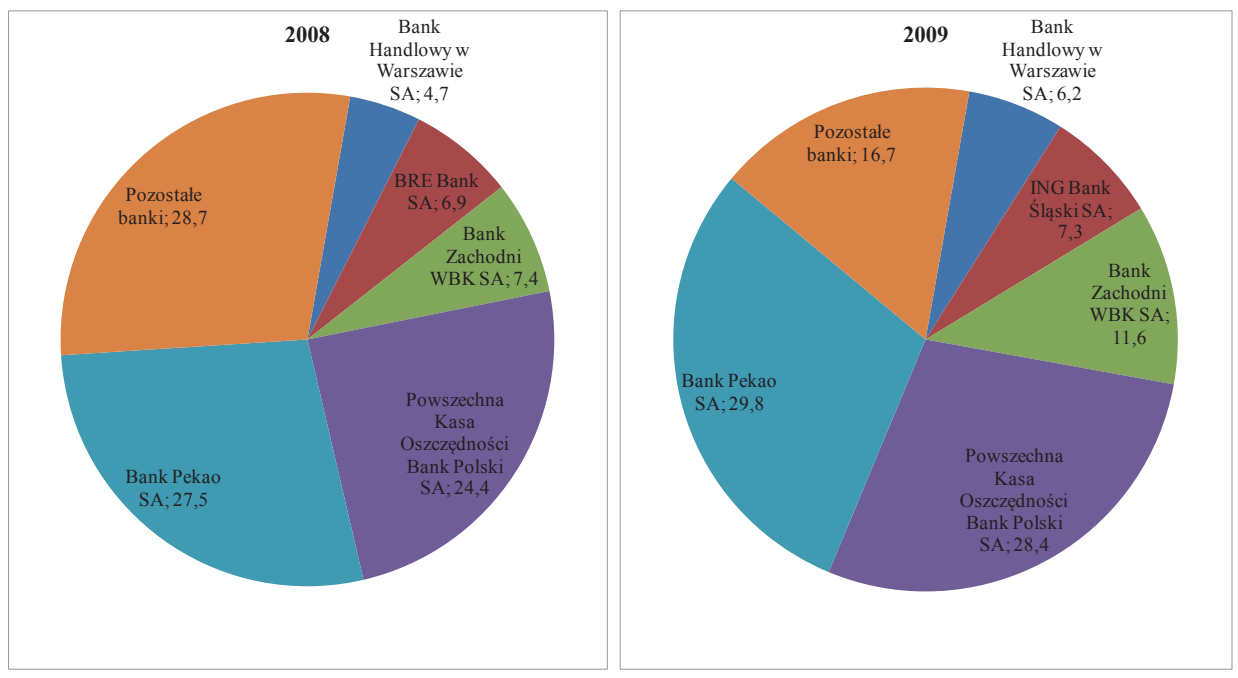

Wykres 5. Udział 5 banków w zyskach banków komercyjnych w latach 2008-2009

Źródło: opracowanie własne.

Kształt krzywej Lorenza dla zysków netto banków komercyjnych (por. wykres 6) wskazuje na relatywnie duże dysproporcje w rozkładzie zysków netto sektora bankowego w Polsce. Spośród 32 banków komercyjnych, które wykazały zysk w 2009 roku, 27 (85\%) osiągnęło łącznie 1,36 mld zł zysku netto (16,7\%). Oznacza to, że musiały się one łącznie zadowolić zyskiem na poziomie tylko nieco ponad połowę przekraczającym zysk osiągany przez Bank Pekao SA czy PKO BP SA z osobna. W efekcie wartość współczynnika Giniego dla rozdysponowania zysków netto w sektorze bankowym wyniosła 78,84\%. W rezultacie wzrastającej koncentracji zysków wskaźnik HHI wzrósł w 2009 roku w porównaniu 
z 2008 rokiem z 0,1538 do 0,1939, co dobitnie oznacza przekroczenie granicy wysokiego poziomu koncentracji.

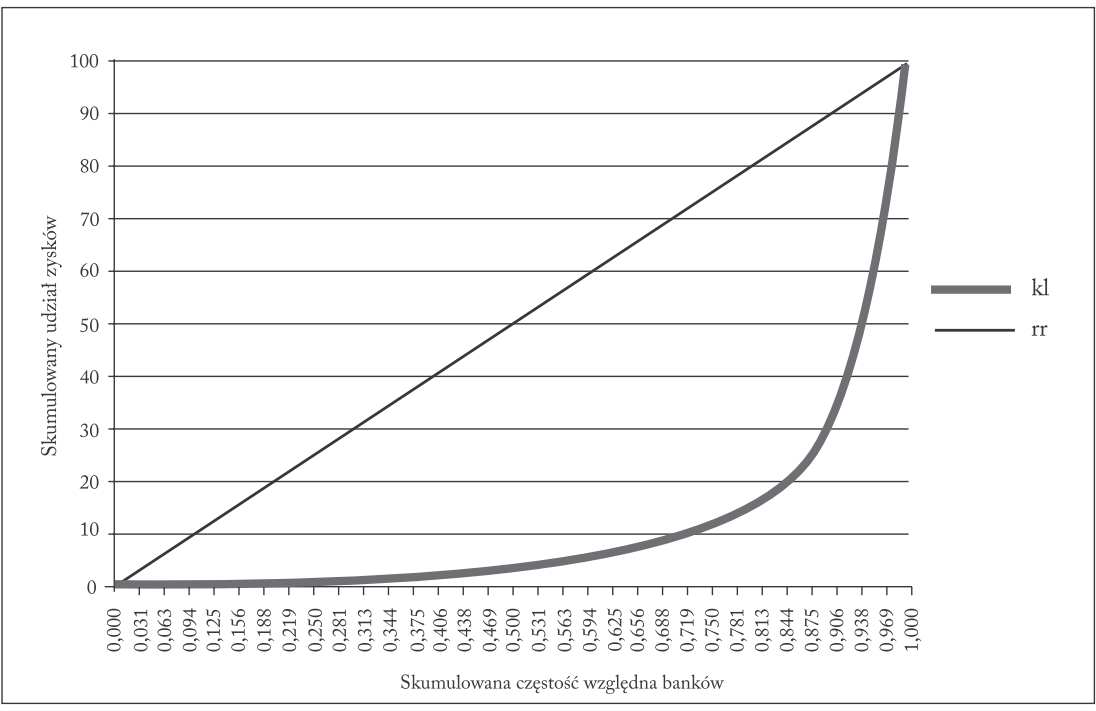

Wykres 6. Rozdysponowanie zysków w sektorze bankowym w Polsce w 2009 roku Uwaga: Wartość współczynnika Giniego: $G_{1}=78,84 \% ; G_{2}=81,38 \%$.

Źródło: opracowanie własne.

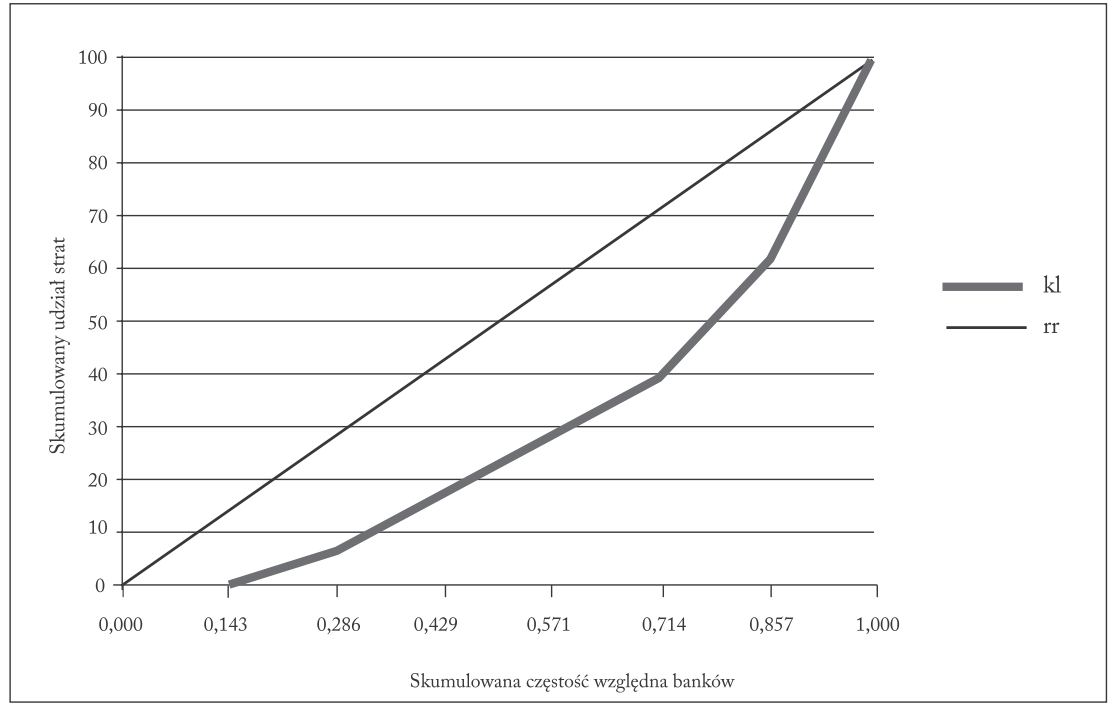

Wykres 7. Rozdysponowanie strat w sektorze bankowym w Polsce w 2009 roku Uwaga: Wartość współczynnika Giniego: G1 = 40,88\%; G2 = 47,69\%.

Źródło: opracowanie własne. 
Bardziej równomierny rozkład wykazują straty sektora bankowego (por. wykres 7). W 2009 roku 7 banków odnotowało stratę, rok wcześniej 5. Znamienny jest wzrost strat z 292,5 mln zł w 2008 roku do 1179,2 mln zł w 2009 roku. W 2009 roku minimalna wartość straty wynosiła 800 tys. zł, a maksymalna blisko $430 \mathrm{mln}$ zł. Wartość współczynnika Giniego dla rozdysponowania strat wyniosła $40,88 \%$, co wskazuje na dwukrotnie bardziej równomierne rozdysponowanie strat niż zysków w sektorze bankowym.

\section{ZAKOŃCZENIE}

Obliczone wartości wskaźników koncentracji sektora bankowego w Polsce wskazują na istnienie konkurencyjnej struktury rynku usług bankowych, co zgodne jest z wynikami innych badań. Przy tym stopień koncentracji zdecydowanie różni się w odniesieniu do rozkładu aktywów i rozkładu wyników netto banków komercyjnych. Aktywa banków komercyjnych są nieskoncentrowane, co prowadzi do wniosku o istnieniu silnej konkurencji międzybankowej. Natomiast wyniki banków komercyjnych, zwłaszcza zyski netto, cechuje wysoki poziom koncentracji, co wskazuje na dominującą pozycję kilku największych podmiotów na rynku.

W zależności od dalszego przebiegu procesu konsolidacji w sektorze bankowym rola kilku wiodących instytucji bankowych może wzrastać, co w efekcie doprowadzi do wzrostu koncentracji rynku usług bankowych i spadku konkurencji międzybankowej. Podmioty o najwyższych zyskach mogą przejmować banki nierentowne lub o rentowności niezadowalającej dla ich dotychczasowych właścicieli. Możliwe są także przejęcia banków bardzo rentownych od właścicieli instytucjonalnych z Europy Zachodniej, którzy zainteresowani są ratowaniem swoich podmiotów na innych rynkach niż polski i w związku $\mathrm{z}$ tym wyzbywają się aktywów w Polsce. Przykładem takich prób - jak dotąd nieudanych - ze strony PKO BP SA były chęć przejęcia Banku Zachodniego WBK SA oraz Polbanku EFG. Bank Zachodni WBK znacząco wzmocnił na polskim rynku hiszpańską grupę kapitałową Santander, podczas gdy Polbank EFG wzmocnił pozycję na rynku detalicznych usług bankowych Raiffeisen Bank Polska SA. Potencjalnie możliwe kolejne fuzje podmiotów składających się na polski sektor bankowy będą wpływać na wzrost koncentracji rynku ${ }^{16}$.

16 W najbliższej przyszłości Banco Comercial Portugues planuje odsprzedać Millenium Bank SA (6). Wśród potencjalnych inwestorów wymieniani są (w nawiasie podano miejsce w rankingu banków komercyjnych w Polsce pod względem aktywów): Raiffeisen Bank Polska SA (11), PKO BP SA (1), BNP Paribas (14 przez Fortis bank Polska SA) i Deutsche Bank (15). 


\section{BIBLIOGRAFIA}

Affinito M., Piazza M., What determines banking structures in European regions?, Bank of Italy Working Paper, 2005, No. 8.

Bikker J.A., Groeneveld J.M., Competition and Concentration in the EU Banking Industry, "Journal of Banking and Finance” 2002, No. 26.

Claessens S., Laeven L., What Drives Bank Competition? Some International Evidence, "Journal of Money, Credit and Banking” 2004, No. 36.

Dixon P.M., Weiner J., Mitchell-Olds T., Woodley R., Erratum to 'Bootstrapping the Gini Coefficient of Inequality', „Ecology” 1988, No. 4, s. 1307.

Emmons W.R., Schmid F.A., Bank Competition and Concentration: Do Credit Unions Matter?, „Federal Reserve Bank of St. Louis Review” 2000, vol. 82, No. 3.

Fuzje i przejęcia bankowe, red. E. Balcerowicz, Zeszyty BRE Bank - CASE, nr 45, Warszawa 1999.

Gelos R.G., Roldos J., Consolidation and Market Structure in Emerging Banking Systems, IMF Working Paper 2002, No. 2(186).

Giannetti C., Intensity of Competition and Market Structure in the Italian Banking Industry, „CORE Discussion Papers” 2007, No. 41.

Glasser G.J., Variance formulas for the mean difference and coefficient of concentration, „Journal of the American Statistical Association"1962, No. 57.

Jackowicz K., Kowalewski O., Koncentracja dziatalności sektora bankowego w Polsce w latach 1994-2000, NBP, Materiały i Studia 2002, nr 143.

Kraciuk J., Procesy konsolidacji w polskim sektorze bankowym, [w:] Problemy rolnictwa światowego, red. H.M. Szoege, W.E. Tyner, Zeszyty Naukowe SGGW, t. XV, Warszawa 2006.

Light R.J., Margolin B.H., An analysis of variance for categorical data, "Journal of the American Statistical Association" 1971, No. 66.

Lorenz M.O., Methods of measuring the concentration of wealth, „Publications of the American Statistical Association” 1905, vol. 9, No. 70.

Pawłowska M., Competition in the Polish Banking Sector, „Gospodarka Narodowa” 2010, nr 5-6.

Pawłowska M., Wptyw procesów konsolidacyjnych na poziom konkurencji i efektywnośc systemów bankowych - wyniki badań ilościowych, [w:] Konkurencyjnośc sektora bankowego po wejsciu Polski do Unii Europejskiej, red. E. Balcerowicz, Zeszyty BRE Bank - CASE, 2005, nr 76.

Pawłowska M., Wptyw zmian w strukturze polskiego sektora bankowego na jego efektywnośc w latach 1997-2002 (podejście nieparametryczne), „Bank i Kredyt”2003, nr 11-12.

Stępień K., Konsolidacja a efektywnośc banków w Polsce, CeDeWu, Warszawa 2004. 


\section{MERGERS AND ACQUISITIONS IN THE BANKING SECTOR AND THE COMPETITIVE STRUCTURE OF THE BANKING SERVICES MARKET IN POLAND SINCE 2004}

SUMMARY

Competition in the banking market remains of constant interest to researchers, because of the role that the banking sector plays in the country's financial system. The purpose ofthis study is to analyze the level of market concentration of banking services in Poland, five years after accession to the European Union. In the empirical part of the article the value of the structural measures of concentration in relation to assets and net income of commercial banks was estimated, as the concentration ratio $C R_{n}$, for $n$ equal to 5,10 and 15, the Gini coefficient and the Herfindahl-Hirschman index. In terms of assets concentration, obtained results indicate a stable share of the five largest commercial banks in the banking services market in Poland, with a decreasing degree of concentration in general, due to the rapid growth of bank assets of small and medium enterprises. However, the income distribution in the banking sector is uneven. All indicators calculated by reference to net profits point to a high level of concentration of the banking services market. 


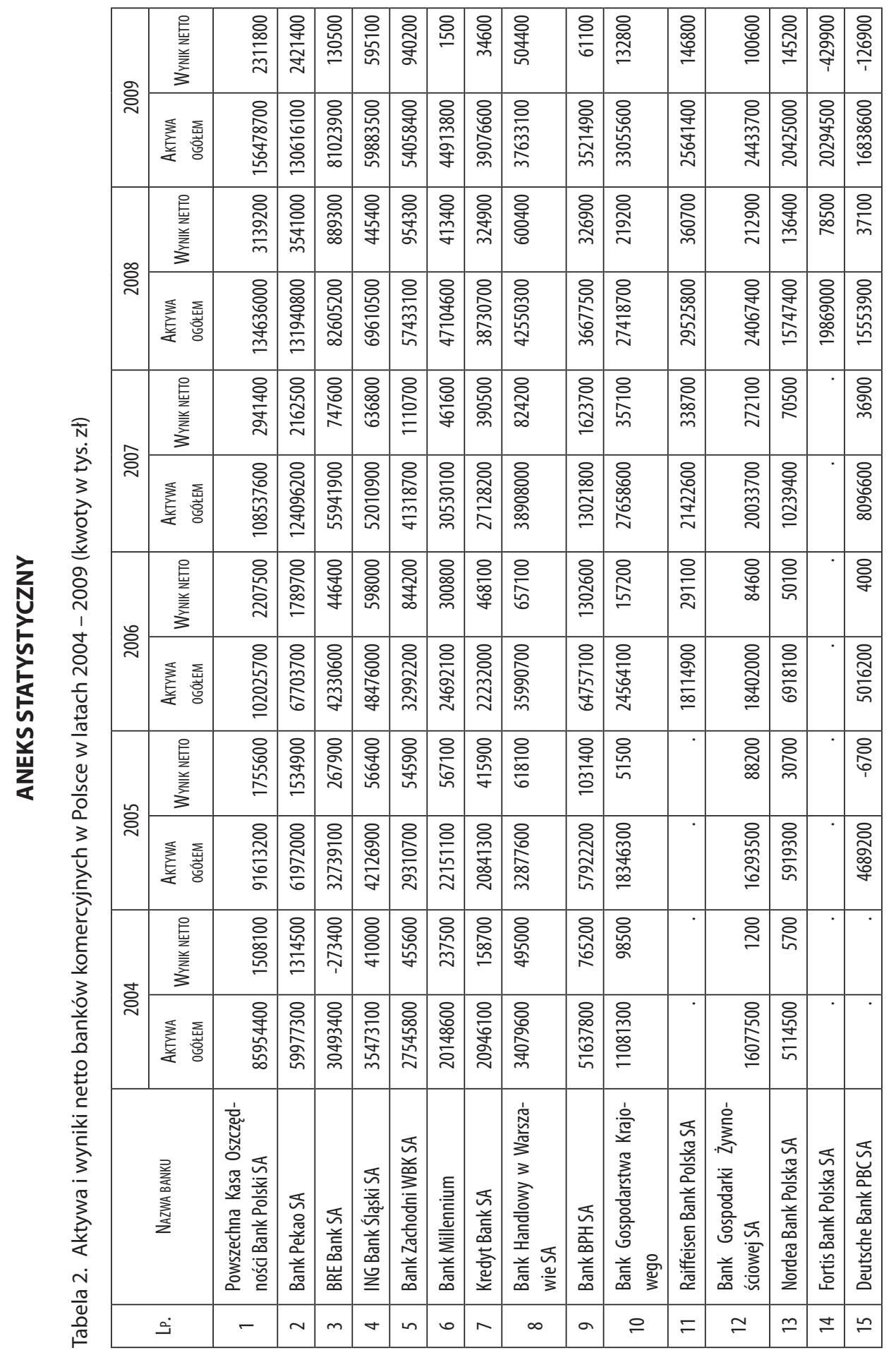




\begin{tabular}{|c|c|c|c|c|c|c|c|c|c|c|c|c|c|c|c|c|}
\hline \multirow[b]{2}{*}{$\stackrel{2}{2}$} & $\begin{array}{l}\text { 鹿 } \\
\text { 差 }\end{array}$ & 高 & 总 & \begin{tabular}{|l|} 
莺 \\
\end{tabular} & 善 & $\begin{array}{l}\text { 商 } \\
\text { în }\end{array}$ & \begin{tabular}{|l|} 
\\
O \\
a
\end{tabular} & $\begin{array}{l}\text { 总 } \\
\text { T. }\end{array}$ & \&্থ & 웡 & & & 总 & 总 & ঃ్ & \\
\hline & 重愛 & \begin{tabular}{|l} 
员 \\
$\stackrel{\text { I }}{\Xi}$
\end{tabular} & 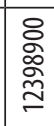 & \begin{tabular}{|l} 
怘 \\
总
\end{tabular} & $\begin{array}{l}\text { 을 } \\
\text { 을 }\end{array}$ & 离 & 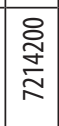 & 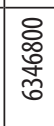 & 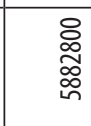 & $\begin{array}{l}\text { Oे } \\
\text { 密 }\end{array}$ & & & 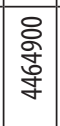 & 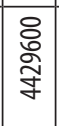 & 悆 & \\
\hline \multirow[b]{2}{*}{ 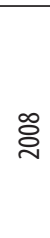 } & 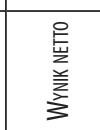 & 总 & 离 & \&্ল & \begin{tabular}{|l} 
\\
o. \\
d
\end{tabular} & 응 & 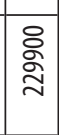 & 㕸 & 윰 & 总 & 罱 & 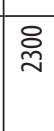 & \begin{tabular}{|l|}
$\frac{8}{\gamma}$ \\
\end{tabular} & \begin{tabular}{|l|} 
\\
\\
2
\end{tabular} & 음 & \\
\hline & 喜営 & 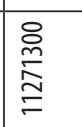 & $\begin{array}{l}\text { 总 } \\
\text { 尊 }\end{array}$ & 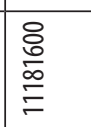 & 空 & $\begin{array}{l}\text { 总 } \\
\text { a }\end{array}$ & 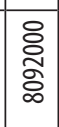 & 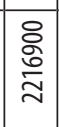 & $\begin{array}{l}\text { : } \\
\text { D. } \\
\text { in }\end{array}$ & 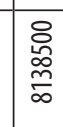 & $\begin{array}{l}\text { 离 } \\
\text { in }\end{array}$ & $\begin{array}{l}\text { 을 } \\
\text { 商 }\end{array}$ & 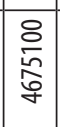 & \begin{tabular}{|l|}
$\frac{8}{y}$ \\
夏
\end{tabular} & 憲 & \\
\hline \multirow[b]{2}{*}{ ఏ্ণ } & 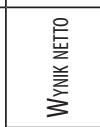 & 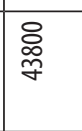 & $\begin{array}{l}\text { 总 } \\
\text { N }\end{array}$ & 兽 & & 产 & 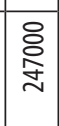 & & 总 & & 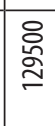 & 亲 & \begin{tabular}{|l|l} 
㧫 \\
\end{tabular} & \begin{tabular}{|l|} 
\\
o \\
\end{tabular} & 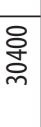 & \\
\hline & 踥㩊 & \begin{tabular}{|l}
\multirow{2}{*}{} \\
总
\end{tabular} & 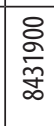 & 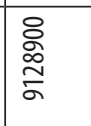 & & 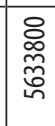 & 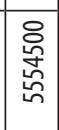 & & 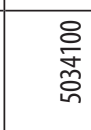 & & 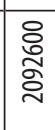 & $\begin{array}{l}\text { 总 } \\
\widetilde{\sim} \\
\tilde{n}\end{array}$ & \begin{tabular}{|l|l} 
\\
0 \\
0 \\
0 \\
$m$
\end{tabular} & \begin{tabular}{|l|}
\multirow{2}{0}{} \\
$\frac{0}{0}$ \\
\end{tabular} & 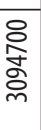 & \\
\hline \multirow{2}{*}{ ¿े. } & $\begin{array}{l}\text { 高 } \\
\text { 美 }\end{array}$ & 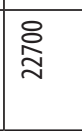 & 总 & 음 & & : & 高 & & 客 & & 总 & 兽 & \begin{tabular}{|l|} 
o \\
pon
\end{tabular} & \begin{tabular}{|l|} 
\\
\multirow{d}{*}{} \\
\end{tabular} & 䞮 & \\
\hline & 喜㩊 & 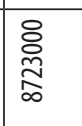 & 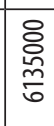 & \begin{tabular}{|l}
8 \\
惫 \\
$\infty$
\end{tabular} & & 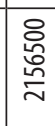 & $\begin{array}{l}\text { 兽 } \\
\text { in }\end{array}$ & & $\begin{array}{l}\text { 总 } \\
\text { 岁 }\end{array}$ & & $\begin{array}{l}\text { 竞 } \\
\text { 多 }\end{array}$ & 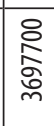 & \begin{tabular}{|c|} 
\\
o. \\
ָे
\end{tabular} & 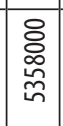 & 裹 & \\
\hline \multirow{2}{*}{ ఏ్రి } & 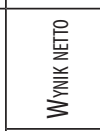 & 总 & 总 & $\begin{array}{l}8 \\
\text { 夏 }\end{array}$ & & $\underset{ }{\stackrel{O}{ }}$ & 兽 & & 옹 & О్ల & & 紊 & 兽 & 委 & & 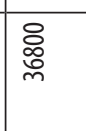 \\
\hline & 椄営 & \begin{tabular}{|l}
8 \\
总 \\
\end{tabular} & 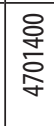 & 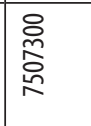 & & 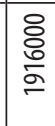 & 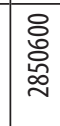 & & $\begin{array}{l}\text { o } \\
\text { oي } \\
\text { m }\end{array}$ & $\begin{array}{l}\stackrel{8}{2} \\
\text { ga }\end{array}$ & & $\begin{array}{l} \\
\text { o } \\
\text { of } \\
\text { of }\end{array}$ & 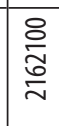 & 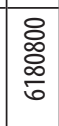 & 昱 & 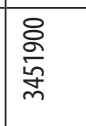 \\
\hline \multirow{2}{*}{ ఫ্ } & $\begin{array}{l}\text { 产 } \\
\text { 雍 }\end{array}$ & 总 & & 总 & & & 递 & & $\begin{array}{l}\text { 享 } \\
\end{array}$ & 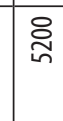 & & $\begin{array}{l}\text { 品 } \\
\text { g }\end{array}$ & & & ఫ్ర్ & 兽 \\
\hline & 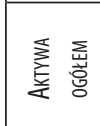 & 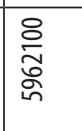 & & $\begin{array}{l}8 \\
8 \\
0 \\
0 \\
6\end{array}$ & & & 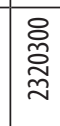 & & $\begin{array}{l}\text { 景 } \\
\text { 空 }\end{array}$ & 息 & & 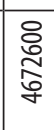 & & & & $\begin{array}{l}\text { 孞 } \\
\stackrel{0}{m}\end{array}$ \\
\hline & $\begin{array}{l}\text { 㝨 } \\
\text { 商 } \\
\frac{1}{2}\end{array}$ & 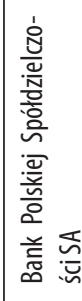 & 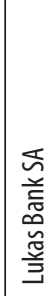 & 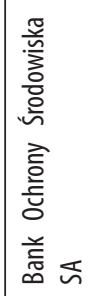 & 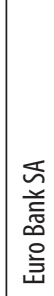 & 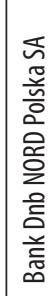 & 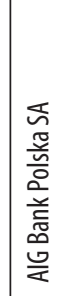 & 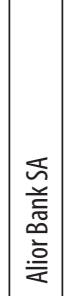 & 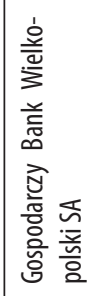 & 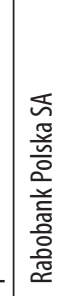 & 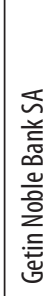 & 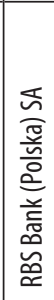 & 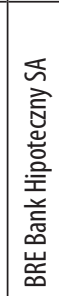 & 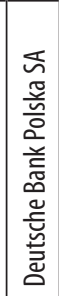 & 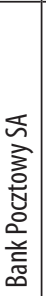 & 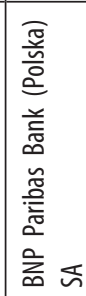 \\
\hline & د. & 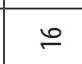 & $=$ & $\propto$ & 9 & ㄱ & $\bar{\sim}$ & $\approx$ & $\approx$ & I & $\approx$ & $\stackrel{\sim}{\infty}$ & $\approx$ & $\infty$ & จิ & m \\
\hline
\end{tabular}




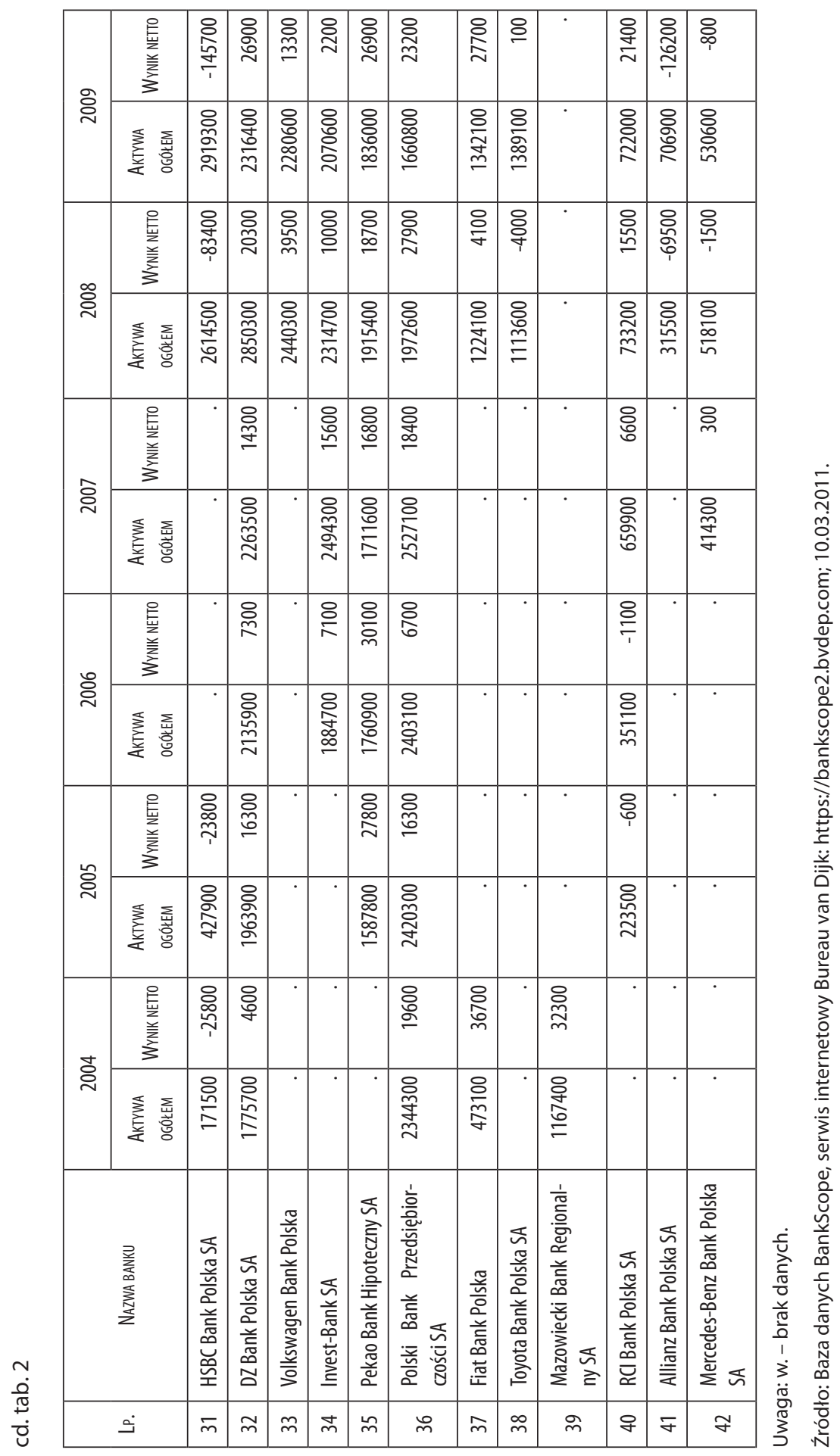


MISCELLANEA 
